\title{
An approach to investigate the effects of climate change on landslide hazard at a national scale (Romania)
}

\author{
Marta Jurchescu, Dana Micu, Mihaela Sima, \\ Dan Bălteanu, Carmen Dragotă, Mihai Micu \\ Institute of Geography, Romanian Academy (IGAR) \\ Bucharest, Romania \\ marta_jurchescu@yahoo.com
}

\author{
Roxana Bojariu, Alexandru Dumitrescu \\ National Meteorological Administration (ANM) \\ Bucharest, Romania \\ bojariu@meteoromania.ro
}

\author{
Francisc Senzaconi \\ General Inspectorate for Emergency Situations (IGSU) \\ Bucharest, Romania \\ senzacof@mai.gov.ro
}

\begin{abstract}
It is widely recognized that climate change is affecting slope stability. However, there is still a great knowledge gap on landslide-climate interaction, while in data-scarce regions, like Romania, it is even less clear how landslide occurrence probability will evolve in response to climate change. The present study proposes a methodological framework for assessing the potential effects of climate change on landslide hazard at a national scale, under current (1961-2015) and future climate (2021-2050). The research approach for developing landslide hazard scenarios relies on the historical landslide inventory of the General Inspectorate for Emergency Situations (IGSU) (20052015), updated observational meteorological data and EUROCORDEX projections of six GCM-RCM runs under two new IPCC scenarios (RCP4.5 and RCP8.5). Precipitation observation and projection data are analyzed in close relation to the landslide events reported within the historical landslide inventory, in order to develop national rainfall-induced landslide hazard scenarios. Maps displaying projected climate change impacts upon landslide hazard patterns and levels are constructed. Future climate-driven evolution trends on landslide occurrences are identified and discussed. Their understanding is expected to support landslide risk management at both national and regional scales. The study was conducted in the framework of the RORISK “Disaster Risk Evaluation at National Level” project, aimed to support the fulfillment of the EU ex-ante conditionality 5.1, co-financed under the European Social Fund through the Operational Program Administrative Capacity 2014 - 2020 and coordinated by IGSU.
\end{abstract}

Keywords-landslide hazard; climate change impact; national scale; extreme climate indices; Romania

\section{INTRODUCTION}

It is generally acknowledged that climate change has implications on slope stability and landslide hazard and that this influence can manifest itself at various spatial and

This study was developed in the framework of the RO-RISK project (“Disaster Risk Evaluation at National Level”, SIPOCA code: 30, 2016), coordinated by the Romanian General Inspectorate for Emergency Situations (IGSU) and co-financed by the European Social Fund through the Operational Program for Administrative Capacity (POCA). temporal scales [e.g. 1, 2, 3]. Over the recent years, studies devoted to this topic have been increasing continuously, however at a rate which is lower than the one of the total landslide literature [4]. A series of aspects regarding the location, extent, magnitude or the course of the induced changes remain unclear [2, 4]. Hence, there is a continuing need to understand how climate change will affect landslide occurrence and associated hazards and risks.

Precipitation is one of the most common trigger of landslides [5, 6], but landslide-climate interactions have a great specificity, which generally relies on local physicalgeographical settings. Although it is recognized that Romania represents one of the landslide hotspots on the European map $^{[1]}$ and that landslides are mainly triggered by heavy rainfall or rainfall overlapping snowmelt, there were only very few attempts to relate landslide occurrences in Romania to climate and particularly rainfall. The studies were usually restricted to single sites or areas of small extents and selected rainfall events and only a few implied spatial analyses [a review in $7 ; 8$ ]. A first effort to understand the impact of a changing climate on the evolution of landslide hazard at regional level has been done in the frame of the FP7 ECLISE project $^{[2]}$ [9]. However, a nation-wide overview on the expected effects of climate change on landslide hazard and risk on the Romanian territory is still lacking.

The RO-RISK (Disaster Risk Evaluation at National Level) project was undertaken in 2016, being coordinated by the General Inspectorate for Emergency Situations (IGSU) and co-financed by the EU through the European Social Fund in the frame of the Operational Program Administrative Capacity 2014 - 2020. Focusing on assessing the specific hazards and risks occurring on the Romanian territory, the project was

\footnotetext{
${ }^{1}$ http://www.changes-itn.eu

${ }^{2}$ http://www.eclise-project.eu
} 
aimed at strengthening risk prevention and management in the country. It provided, among others, the framework for assessing landslide hazard and risk at the national level. The current paper presents some preliminary results achieved within the RO-RISK project regarding the development of a methodological framework for evaluating the potential impacts of climate change on landslide hazard at a national level, by utilizing future climate projections and a landslide hazard scenario design.

\section{Climate DAta ANALysis}

Gridded precipitation information provided by the National Meteorological Administration (ANM), derived from both meteorological observation records (1961-2015) and climate projections (2021-2050), were used to analyze past periods of landslide occurrence and to model precipitation-driven landslide hazard at a national scale. The landslide preparing/triggering role of precipitation was expressed by means of six precipitation extremes indices - 10year and 100-year return values of 3-day precipitation, wet spell length and seasonal rainfall. These were selected from a more extended list of precipitation extreme indices computed for different return periods (5, 10, 30, 50, 100 and 1000 years), in order to comply with the project's requirements and because they were considered suitable for landslide occurrence. The selected precipitation extreme indices were used to develop national landslide hazard scenarios, under both current and future climatic conditions. Information on future extreme precipitation was derived from the projections of a selection of six EURO-CORDEX GCM-RCM simulations (Table I) available at a horizontal resolution of $12.5 \mathrm{~km}$ (and downscaled at $1 \mathrm{~km}$ ), most reliable in reproducing the current climatic conditions [10]. The selected six models performed under IPCC emission scenarios RCP4.5 and RCP8.5. From this selection, the projections of two GCM-RCM runs have been particularly considered when analyzing landslide hazard under a wetter (IPSL-INERIS-WRF331F) and a drier (KNMIRACMO22E) future climate.

TABLE I. SELECTED EURO-CORDEX CLIMATE MODELS FOR ASSESSING FUTURE LANDSLDIE HAZARD IN ROMANIA [10]

\begin{tabular}{|c|c|c|c|}
\hline \multirow[t]{2}{*}{ No. } & \multicolumn{3}{|c|}{ EURO-CORDEX climate projections } \\
\hline & Regional climate model centers & $\begin{array}{c}\text { Regional } \\
\text { climate model } \\
(\mathrm{RCM})\end{array}$ & $\begin{array}{c}\text { Global } \\
\text { climate model } \\
(G C M)\end{array}$ \\
\hline 1 & $\begin{array}{ll}\text { CLMcom } & \text { (CLMcom } \\
\text { Consortium) } & \\
\end{array}$ & CLM 4-8-17 & $\begin{array}{l}\text { MPI-ESM- } \\
\text { LR }\end{array}$ \\
\hline 2 & $\begin{array}{l}\text { DMI (Dansih Meteorological } \\
\text { Institute) }\end{array}$ & HIRHAM5 & $\begin{array}{l}\text { ICHEC-EC- } \\
\text { EARTH }\end{array}$ \\
\hline 3 & $\begin{array}{l}\text { IPSL-INERIS (Laboratoire } \\
\text { des Sciences du Climat et de } \\
\text { l'Environnement, IPSL, } \\
\text { CEA/CNRS/UVSQ - Institut } \\
\text { National de l'Environnement } \\
\text { Industriel et des Risques) }\end{array}$ & WRF 331F & $\begin{array}{c}\text { IPSL- } \\
\text { CM5A-MR }\end{array}$ \\
\hline 4 & $\begin{array}{l}\text { KNMI (Royal Netherlands } \\
\text { Meteorological Institute) }\end{array}$ & $\begin{array}{l}\text { RACMO } \\
22 \mathrm{E}\end{array}$ & $\begin{array}{l}\text { ICHEC-EC- } \\
\text { EARTH }\end{array}$ \\
\hline 5 & $\begin{array}{l}\text { MPI-CSC (Max-Plank } \\
\text { Institute for Meteorology - } \\
\text { Climate Service Center) }\end{array}$ & REMO 2009 & $\begin{array}{c}\text { MPI-ESM- } \\
\text { LR }\end{array}$ \\
\hline 6 & $\begin{array}{lr}\text { SMHI } & \text { (Swedish } \\
\text { Meteorological } & \text { and }\end{array}$ & RCA4 & $\begin{array}{l}\text { ICHEC-EC- } \\
\text { EARTH }\end{array}$ \\
\hline
\end{tabular}

\begin{tabular}{|l|l|c|c|}
\hline \multirow{2}{*}{ No. } & \multicolumn{3}{|c|}{ EURO-CORDEX climate projections } \\
\cline { 2 - 4 } & Regional climate model centers & $\begin{array}{c}\text { Regional } \\
\text { climate model } \\
\text { (RCM) }\end{array}$ & $\begin{array}{c}\text { Global } \\
\text { climate model } \\
\text { (GCM) }\end{array}$ \\
\hline & Hydrological Institute) & & \\
\hline
\end{tabular}

\section{Assessing the EFFect of Climate Change ON} LANDLSIDE OCCURRENCES

A nation-wide database of recent historical damaging landslides, integrated and provided by IGSU, was used to investigate the relation between landslide occurrences and climate. The information was recorded by the civil protection county inspectorates and covers the 2005-2015 time interval. The database comprises over 3700 records distributed across 31 counties. However, the data is believed to have a heterogeneous character in terms of location and temporal accuracies and completeness.

The recent historical landslide data enabled to retrieve the rainfall indicator values (seasonal rainfall, intervals of consecutive wet days, 3-day precipitation) corresponding to landslide occurrences. In order to remove possible biases affecting this relationship, mainly due to the vertical zonation of climatic parameters as well as to the different local climatic influences present on the Romanian territory, rainfall variables were normalized with the mean annual precipitation and the rainy-day-normal. The analysis of past events was aimed at establishing a relation between the normalized rainfall values and the extent of the geomorphic response in terms of the number of slope failures. The triggering effect of precipitation has been shown to vary with terrain predisposing conditions, i.e. for landslides to initiate in less susceptible regions higher rainfall quantities are needed than those associated to landsliding at the most susceptible slopes. Therefore, a susceptibility zonation of the Romanian territory was first required in order to separate among areas having different geological, topographic and land-use conditions [11].

This type of analysis, accounting for regional and temporal variability of the main factors involved in hazard analysis (spatial probability, intensity of the trigger, response magnitude), allowed to maximize the use of the rather reduced volume of landslide data considered both accurate and complete and limited to the territories of only a few counties. Therefore, a relationship established on a limited area of the country could be extrapolated to the rest of the country's territory by considering the differences induced by morphostructural, lithological and meteorological settings.

Hazard scenarios were built by overlaying the slide susceptibility map with several other maps displaying the triggering potential of the selected rainfall variables. The triggering potential was achieved by normalizing the climate parameter maps in the same way as for investigating past climate-landslide relations. The overlay procedure was controlled by means of semi-quantitative hazard matrices (susceptibility $x$ triggering potential).

The main limitations of the present research are caused by the quality of the landslide database, in terms of spatial and temporal incompleteness and heterogeneity of registration accuracies. In this context, knowledge derived on the climate- 
landslide relation was not regarded as having any statistical significance. It was merely used to modulate the expert-based hazard scenario matrices.

\section{PRELIMINARY RESUltS AND CONCLUSIONS}

Analyzing the impact of climate on landslide hazard is the most appropriate way when aiming to understand climate effects on landslide occurrence at regional/national scales. This study resulted in the construction of several national rainfall-induced landslide hazard maps. Comparisons between reference and future maps depicting landslide hazard in response to different extreme climate indices revealed some trends to be attributed to climate change. Spatial distribution of landslide hazard is mainly dictated by terrain attributes, especially lithology, and thus most affected are the hilly and plateau regions built of Neogene deposits and the mountainous regions developed on Cretaceous and Paleogene flysch. However, variations in hazard magnitude across these regions for a particular analyzed frequency are expected to be due to variations in the triggering factor.

Future change in seasonal rainfall is expected to induce, under both RCPs, slight increases of landslide activity mainly in the Eastern Carpathians, the Moldavian Subcarpathians and the northern part of the Moldavian Tableland, in case of the 10 -year return period, and extensive increases particularly in the western hilly and plateau areas, in case of the 100-year return period. Decreases in the number of landslides are also possible in the south-western part of Romania. Landslide hazard triggered by short-term, 3-days precipitation indicates an increase in the number of landslides affecting different parts of the Transylvanian area, the Subcarpathian hills and the Moldavian plateau in case of a 10-year recurrence period. When considering a 1/100years frequency, landslide hazard is expected to intensify under the future evolution of highintensity and short-duration precipitation and extend towards the north-eastern part of the country as well as towards the Eastern and the Curvature Carpathians, according to both RCPs. As for future variations in the length of wet intervals associated to a $1 / 10$ years frequency, these are expected to result in more abundant landslide occurrences in the Eastern Carpathians, and possibly in the Apuseni Mountains, parts of the Transylvanian Plateau and the Eastern part of the country (i.e. the Moldavian Plateau and the Moldavian Subcarpathians). Decreases in the landslide activity are also possible, e.g. in areas of the Moldavian Plateau or in the south-western part of the country.

Generally, if considering one trigger proxy as simulated by one single model, landslide hazard increases seem to be more extensive under RCP8.5 than under RCP4.5.

As is the case of any climate-landslide study, several types of epistemic and aleatory uncertainties also affect the current approach and they are related to the main steps of the study: assessment of landslide susceptibility, determination of climate-landslide interactions and relationships, elaboration of landslide hazard maps, future climate modeling and climate data processing, construction of future climate-driven landslide hazard scenarios.
In the context of an undisputable climate warming, expected to affect landslides, this paper proposes a conceptual framework to address the effects of climate change on landslide hazard at a national scale. It provides a first evaluation on the future climate-landslides relation for the national territory of Romania, which, at the same time, represents one of Europe's hotspot areas in terms of landslides. The developed approach allows users to gain a general and rapid appraisal of the projected future climate impacts on landslide occurrence at the national level.

However, given the high uncertainties affecting climatelandslide investigation frameworks, care is recommended when interpreting the expected variations in landslide hazard driven by projected climate change. Future work will aim both at reducing as much as possible existing uncertainties - e.g. by improving the quality of the various input data used and by a more in-depth analysis of the climate-landslides relationship as the basis for understanding future climate impacts - and at quantifying and communicating those uncertainties which will remain inevitable.

\section{ACKNOWLEDGMENT}

The authors wish to thank the IGSU institution, for the good coordination of the RO-RISK project and their continuous support, as well as the other partner institutions involved in the landslide research: the Technical University of Civil Engineering (UTCB), the National Institute for Research and Development in Constructions, Urban Planning and Sustainable Spatial Development (URBAN-INCERC) and the National Institute for Earth's Physics (NIEP). They also express their appreciation to the entire team of personnel involved in the different parts of the study.

\section{REFERENCES}

[1] R.C. Sidle and H.Ochiai, "Landslides: processes, prediction, and land use”. Water Resour. Monogr., vol. 18. Washington DC: AGU, 2006, 312 pp.

[2] M.J. Crozier, "Deciphering the effect of climate change on landslide activity: a review”, Geomorph., vol. 124, pp. 260-267, 2010.

[3] J.A. Coe and J.W. Godt, "Review of approaches for assessing the impact of climate change on landslide hazards", in Landslides and Engineered Slopes, Protecting Society Through Improved Understanding: Proceedings 11th International and 2nd North American Symposium on Landslides and Engineered Slopes, E. Eberhardt, C. Froese, A.K. Turner, S. Leroueil, Eds. Banff, CA: Taylor \& Francis Group, June 2012, pp. 371-377.

[4] S.L. Gariano and F. Guzzetti, „Landslides in a changing climate”, EarthSci. Rev., vol. 162, pp. 227-252, 2016.

[5] M. Crozier, "Landslides: causes, consequences and environment". London: Croom Helm, 1986, 252 pp.

[6] J. Corominas, "Landslides and climate”, CD-Rom. Cardiff, UK., 33 pp., 2001 [Keynote Lectures, 8th Intern. Symp. on Landsl., 2000]

[7] M. Micu, M. Jurchescu, I. Șandric, M.C. Mărgărint, Z. Chițu, D. Micu, R. Ciurean, V. Ilinca, and M. Vasile, "Mass Movements", in Landform Dynamics and Evolution in Romania, M. Rădoane and A. VespremeanuStroe, Eds., Springer, 2017, pp. 765-820.

[8] Z. Chiţu, T. Bogaard, A. Busuioc, S. Burcea, I. Țandric, and M.-J. Adler "Identifying hydrological pre-conditions and rainfall triggers of slope failures at catchment scale for 2014 storm events in the Ialomita Subcarpathians, Romania”, Landslides, vol. 14, pp. 419-434, 2017. 
[9] M. Jurchescu et al., unpublished.

[10] R. Bojariu et al., Schimbările climatice - de la bazele fizice la riscuri și adaptare. București: Printech, 2015, 200 pp. (in Romanian)
[11] D. Bălteanu et al., unpublished. 